\title{
PLURALISME AGAMA MENURUT ABRAHAM KUYPER DAN KONTRIBUSINYA BAGI PENGEMBANGAN PENDIDIKAN AGAMA KRISTEN
}

\author{
Desi Sianipar \\ Universitas Kristen Indonesia \\ desi.sianipar07@gmail.com
}

\begin{abstract}
Abstrak
Tulisan ini merupakan kajian terhadap konsep pluralisme agama menurut Abraham Kuyper (1837-1920), seorang Belanda yang memiliki keahlian dalam bidang agama, politik, dan pendidikan. Studinya yang mendalam mengenai ilmu-ilmu ini telah menghasilkan pemikirannya yang khas mengenai pluralisme agama. Keunikan pemikirannya terletak pada konsep kebebasan dan teologi Calvinis di Amerika. Tulisan ini merupakan tinjauan pustaka yang diharapkan dapat memberikan wawasan dan pengetahuan yang bermanfaat bagi pengembangan pendidikan agama Kristen. Beberapa kontribusi pemikiran Kuyper yang dapat dikembangkan dalam pendidikan agama Kristen adalah Tuhan adalah pencipta keberagaman; keberagaman agama harus menghasilkan kebaikan; mengakui keberagaman sama dengan mengakui manusia sebagai gambar Allah. Karena itu, keberagaman agama harus bisa didialogkan secara terbuka.
\end{abstract}

Kata Kunci: pluralisme, Abraham Kuyper, pengembangan, pendidikan agama Kristen.

\section{A. Pendahuluan}

Pluralisme tetap menjadi pokok yang penting untuk dipikirkan, dikaji, dan dihidupkan kembali secara terus-menerus dalam kehidupan berbangsa dan bernegara sebab setiap negara pasti mengandung kemajemukan. Pluralisme menunjukkan adanya perbedaan dan keberagaman dalam berbagai hal (budaya, agama, bahasa, pandangan politik, etnisitas), yang bisa saja menguntungkan dan menimbulkan masalah dalam suatu masyarakat. Sebagai suatu kenyataan yang tidak bisa ditolak, pemahaman dan kesadaran akan pluralisme ini harus terus dipelihara supaya setiap anggota masyarakat dapat menempatkan dirinya sebagai bagian yang integral dan konstruktif di dalam masyarakat atau dunianya.

\footnotetext{
${ }^{1} \mathrm{KBBI}, \quad$ Pluralisme. https://kbbi.web.id/ pluralisme; https://www.merriam-webster
}

Menurut Kamus Besar Bahasa Indonesia, pluralisme artinya adalah keadaan masyarakat yang majemuk (berkaitan dengan sistem sosial dan politiknya). Di dalam Merriam-Webster Dictionary, pluralisme didefinisikan sebagai "a situation in which people of different social classes, religions, races, etc., are together in a society but continue to have their different traditions and interests.; The belief that people of different social classes, religions, races, etc., should live together in a society". ${ }^{1}$ Berdasarkan kedua kamus tersebut, dipahami bahwa pluralisme adalah suatu situasi dan kondisi masyarakat yang majemuk dalam hal golongan sosial, agama, ras, politik, dsb., tetapi mereka sepakat dan yakin untuk tinggal bersama dalam suatu masyarakat. Akan tetapi

.com/dictionary/pluralism.Diakses tanggal 5 Februari 2019. 
kesalahan yang paling serius yang dibuat oleh para teolog dan para pemimpin agama tertentu adalah memandang teologi atau agama mereka paling benar, dan posisi yang lain adalah salah. Pandangan seperti ini membuat kehidupan yang majemuk seringkali terganggu dan bahkan terancam oleh karena perselisihan, pertengkaran, perkelahian, dan peperangan.

\section{B. Pluralisme Menurut Abraham Kuyper}

Abraham Kuyper (1837-1920) terkenal sebagai teolog Kristen, filsuf, jurnalis, pendidik, pendeta, politikus, dan negarawan yang telah menghasilkan banyak hal yang luar biasa dan telah menulis lebih dari 200 buku dan artikel penting. Selama hidupnya dia telah banyak berperan langsung dalam dunia pendidikan, agama, dan politik. Salah satu perannya yang sangat penting adalah menjadi pemimpin partai AntiRevolusioner Protestan, anggota Parlemen, Menteri Kehakiman, dan Perdana Menteri Belanda (1901-1905). Selain itu, Kuyper terkenal sebagai pengamat hukum Amerika, agama, dan politik, dan banyak yang lainnya. Dia juga adalah pendiri Free University di Amsterdam tahun $1880 .{ }^{2}$ Secara teologis, Kuyper adalah penganut Calvinisme, meskipun kebanyakan orang mengakui bahwa Calvinisme yang dianut oleh Kuyper bukan ajaran asli Calvin, tetapi sudah merupakan pengembangannya. Kuyper lebih mengikuti Vinet ketimbang Calvin dalam hal pemberian lebih sedikit wewenang pada pemerintah dalam

\footnotetext{
${ }^{2}$ Jr. John Witte, The Biography and Biology of Liberty: Abraham Kuyper and the American Experiment. Dalam Luis E. Lugo, ed., Religion, Pluralism, and Public Life: Abraham Kuyper's Legacy for the 21 st Century (Grand Rapids, MI: Wm. B. Eerdmans Publishing Co., 2000), $243-$ 244.
}

kaitannya dengan agama. Dia menganggap Calvinisme sebagai sumber dan jaminan kebebasan konstitusional Belanda. Menurut Kuyper, Calvinisme memiliki pemahaman yang paling dalam tentang kesatuan Allah dengan ciptaanNya, bahwa Allah dalam keagungan-Nya melampaui semua makhluk, namun Allah masih bersekutu dengan manusia melalui Roh Kudus-Nya. ${ }^{3}$ Salah satu pemikirannya yang sangat inspiratif adalah mengenai pluralisme yang dipelajarinya dari fenomena yang berlangsung di Amerika. Pemikirannya ini dijalin dengan pokok kebebasan (liberty) dan teologi Calvinisme.

\section{Kebebasan dan Pluralisme}

Pandangannya tentang pluralisme sangat dipengaruhi oleh pokok kebebasan dalam konteks Amerika. Dalam artikelnya, John Witte, Jr. telah meringkas empat tipe kebebasan dan pluralisme di Amerika yang diamati oleh Kuyper, yaitu: kebebasan hati nurani, kebebasan gerejawi, kebebasan asosiasi, dan kebebasan politik. Dasar dari kebebasan dan pluralisme agama di Amerika adalah hati nurani, yang tampak dalam kebebasan berorganisasi, kebebasan pers, kebebasan beribadah, dan kebebasan berpikir. Hati nurani adalah sumber kepribadian manusia, akar dari hak-hak sipil, dan sumber identitas nasional. Dengan adanya kebebasan hati nurani, maka setiap warga negara bebas untuk membentuk dan mereformasi pendapat keagamaan, untuk masuk dan keluar dari organisasi keagamaan tanpa membahayakan kebebasan sipil lainnya. ${ }^{4}$

\footnotetext{
3 John H. Kromminga, Abraham Kuyper. Dalam Elmer L. Towns (ed.), A History of Religious Educators. www.elmertowns.com., diakses tanggal 4 Februari 2019.

${ }^{4}$ Jr. John Witte, Op. Cit., 245.
} 
Prinsip Amerika mengenai kebebasan gerejawi dan pluralisme konfesional adalah dengan menetapkan pemisahan gereja dan negara. Pemisahan yang dimaksudkan di sini bukan berarti pemisahan agama dan politik sebab para hakim memutuskan perkara tetap dalam rasa takut akan Tuhan dan tetap mengakui dan menghormati hari raya keagamaan, serta menyatakan bahwa mereka menerima hukum dari Tuhan. Pemisahan gereja dan negara artinya adalah gereja-gereja sepenuhnya bebas dari campur tangan negara dalam hal penetapan doktrin dan liturgi, organisasi dan kepemilikan, dalam hal pendidikan dan katekisasi. Pemerintah sadar bahwa kesejahteraan gereja dan kemajuan Kekristenan membutuhkan kebebasan dan kemandirian. ${ }^{5}$ Berdasarkan pemikiran ini, pada tahun 1886 Kuyper menolak ide tentang gereja nasional dengan semua implikasinya. Dia memimpin pemisahan dari Gereja Hervormd Belanda di mana kemudian skisma ini disebut Doleantie (Latin, dolere, 'to feel sorrow'). Bagi Kuyper, keseragaman adalah kutukan atas kehidupan modern, sebaliknya kemajemukan (pluriformitas) dipandang sebagai karunia Tuhan. Gereja nasional sangat berlawanan dengan pemikiran Kuyper karena negara sangat mencampuri urusan pendidikan Kristen di mana negara menentukan apakah dan dimanakah universitas harus didirikan; negara mengangkat rektor, kurator, dan guru; negara mengatur ujian dan nilai; dan menyediakan dana. Reaksi Kuyper dan reaksi gerakan yang terkait dengannya, didasarkan dan didorong oleh ajaran Calvinis bagi seluruh kehidupan. Dia yakin bahwa prinsip-prinsip Kristen sangat terintegrasi dengan kehidupan dan kesejahteraan Belanda. ${ }^{6}$

\footnotetext{
${ }^{5}$ Ibid., 245.

${ }^{6}$ John H. Kromminga, Op. Cit., t.hlm.
}

Prinsip Amerika dalam hal kebebasan asosiasi dan pluralisme sosial tampak dalam tradisi Amerika tentang kesukarelaan dan persaudaraan. Hal ini telah menghasilkan perlindungan hukum yang cukup, bukan hanya bagi gerejagereja dan organisasi keagamaan, tetapi juga bagi pluralitas lingkungan sosial lainnya, seperti: keluarga, sekolah, serikat pekerja, perkebunan, klub, biara, dan korporasi. Otoritas dan kompetensi mereka bergantung pada norma batiniah, kebebasan dari Tuhan, dan kedaulatan di lingkup mereka. Akan tetapi, dengan itu semua, bukan berarti mereka dapat menjadi hukum bagi diri mereka sendiri. Mereka semua tidak bergantung pada pemerintah, tetapi mereka dilindungi oleh pemerintah melalui hukum pidana.

Prinsip kebebasan politik dan pluralisme politik tampak dalam Konstitusi Amerika yang menganut "kesatuan politis federalis" dalam sistem republik yang demokratis, yang menyeimbangkan tuntutan kebebasan dan ketertiban, pemerintahan lokal dan persatuan nasional. Di sisi lain, otoritas politik di Amerika terbagi antara pemerintahan federal, negara bagian, dan lokal. Amerika memiliki pemerintahan federal Amerika yang kuat, yang cenderung pada tuntutan ekonomi, administratif, militer, dan diplomatik bersama sebagai suatu bangsa. Masyarakat Amerika memiliki agama yang kuat, yang mewujudkannya dalam doa dan pemberitaan Firman di lingkungan Kepresidenan, dan jemaat memberikan dukungan untuk pendidikan agama, perlindungan hukum federal berdasarkan moral kardinal dan nilainilai budaya. ${ }^{8}$

\footnotetext{
${ }^{7}$ Jr. John Witte, Op. Cit., 246

${ }^{8}$ Ibid., 247-248.
} 
2. Calvinisme dan Pluralisme

Selain prinsip kebebasan ala Amerika, Kuyper juga membangun pandangannya tentang pluralisme dari teologi Calvinis. Bagi Kuyper, Calvinisme merupakan istilah ilmiah (scientific) dalam pengertian historis, filosofis, dan politis, ketimbang sebagai aliran (sekte), konfesi, dan denominasi. Sebagai hal yang historis, artinya ada hubungan dengan gerakan Reformasi abad ke-16; sebagai hal yang filosofis, Calvinisme dipahami dalam pengertian sistem konsepsi di bawah pengaruh Calvin; dan sebagai hal yang politis, Calvinisme adalah gerakan politik yang menjamin kebebasan bangsa-bangsa secara konstitusional. Sementara itu, Calvinisme dipahami sebagai istilah ilmiah oleh para sarjana Jerman, terutama Robert Fruin yang menyatakan bahwa "Calvinisme yang masuk ke Netherland merupakan sistem logis tentang KeAllah-an; dan menyangkut tata gereja yang demokratis yang didorong oleh perasaan moral yang sangat tinggi. R.C. Bakhuizen van den Brink mengemukakan bahwa Calvinisme adalah bentuk perkembangan tertinggi yang dicapai melalui prinsip politik dan agama pada abad ke-16. CD. Busken Huet menulis bahwa Calvinisme telah membebaskan Switzerland, Netherland, dan Inggris, serta telah mendorong tercapainya kemakmuran Amerika Serikat. ${ }^{9}$

Pemikiran Kuyper tentang Calvinisme disampaikan dalam kuliahkuliahnya di Princeton University. Ada enam pokok Calvinisme yang disampaikannya, yaitu Calvinisme

\footnotetext{
9 Abraham Kuyper, Lectures on Calvinism: Six Lectures Delivered at Princeton University Under Auspices of the L. P. Stone Foundation (Grand Rapids, Michigan: Wm. B. Eerdmans Publishing Company, 1999), 13-17.
}

sebagai sistem kehidupan; Calvinisme dan Agama; Calvinisme dan Politik; Calvinisme dan Ilmu Pengetahuan; Calvinisme dan Seni; Calvinisme dan Masa Depan. ${ }^{10}$ Pemikirannya mengenai pluralisme tampak sangat kuat dalam dua pokok pemikiran: Calvinisme sebagai sistem kehidupan; dan Calvinisme dan agama. Kuyper berpendapat bahwa Calvinisme telah menciptakan bentuk gereja yang beragam; dan bentuk kehidupan manusia yang sangat beragam, untuk melengkapi masyarakat dengan cara keberadaan yang beragam, dan mengisi hati manusia dengan cita-cita dan konsepsi yang beragam. Keberagaman itu bukan berarti menimbulkan hierarkhi atau kasta manusia, tetapi semata-mata karena pengakuan bahwa setiap manusia adalah gambar Allah yang harus dihormati. ${ }^{11}$ Menurut dia, Calvinisme sebagai sistem kehidupan menekankan hubungan manusia dengan sesamanya, dan hubungannya dengan dunia ditentukan oleh pemahaman tentang Allah. Allah adalah pusat segala sesuatu, sehingga mengakui Allah berarti menghargai manusia sebagai gambaran Allah dan menghargai dunia sebagai ciptaan-Nya. Allah telah menyediakan anugerah khusus untuk mengerjakan keselamatan, dan anugerah umum untuk memelihara kehidupan dunia, di mana pada akhirnya semua bertujuan untuk memuliakan Tuhan sebagai Pencipta. Kuyper menyimpulkan bahwa Calvinisme telah menjawab tiga hal menyangkut hubungan manusia dengan Allah, dengan sesama, dan dengan dunia, yaitu: 1) persekutuan langsung antara manusia dengan Allah, yang bebas dari

\footnotetext{
${ }^{10}$ Abraham Kuyper, Lectures on Calvinism: Six Lectures from the Stone Foundation Lectures Delivered at Princeton University (USA: ReadaClassic.com., 2010), 7.

11 Kuyper, Lectures on Calvinism: Six Lectures Delivered at Princeton University, 26-28.
} 
intervensi pendeta dan gereja; 2) pengakuan bahwa setiap pribadi adalah berharga selaku milik dan ciptaan Tuhan yang serupa dengan-Nya, dan semua manusia setara di hadapan Allah sebagai Hakim; 3) pengakuan bahwa di seluruh dunia, kutukan dikendalikan oleh rahmat, bahwa kehidupan di dunia harus dihormati dalam kemandiriannya, dan bahwa setiap manusia dapat memiliki harta dan mengembangkan potensinya di dunia dan dalam kehidupan manusia. ${ }^{12}$

Pada pokok tentang Calvinisme dan agama, menurut Kuyper, di dalam Calvinisme diakui adanya fungsi positif agama untuk menghasilkan kebaikan dan berkat bagi manusia, tetapi agama bukan dihadirkan untuk kepentingan manusia, tetapi untuk kepentingan Allah karena segala sesuatu diciptakan untuk kepentingan-Nya. Agama adalah titik berangkat dan tujuan akhir dari segala sesuatu. Orang yang tidak beragama berarti meninggalkan tujuan tertinggi dari keberadaan manusia, dan tidak mengingini keberadaan, kehendak, dan kemuliaan Tuhan, karena itulah inti dari semua agama yang benar. Pengakuan akan kedaulatan Tuhan yang absolut adalah konsepsi dasar agama sebagaimana dipertahankan oleh Calvinisme. Tuhan adalah kekuatan aktif yang membuat manusia menjadi religius sehingga tidak perlu ada manusia lain yang memperantarai hubungan manusia dan Allah. Manusia harus mampu berhadapan langsung secara personal dengan Allah. Agama seharusnya bersifat membebaskan secara rohani, tidak boleh menekan atau menindas. Dari perspektif Calvinisme, kebebasan spiritual memungkinkan orang percaya untuk menentang pejabat gereja yang merasa paling kuat, bila diperlukan dan untuk kepentingan Tuhan. Orang percaya dapat

\footnotetext{
12 Ibid., 30-31.

13 Ibid., 44-48.
}

berdiri di hadapan Tuhan menurut pertimbangannya sendiri, dan menikmati persekutuan dengan Tuhan tanpa gangguan, dan memperlihatkan kebebasannya yang mulia. ${ }^{13}$

Lebih lanjut Kuyper berpendapat bahwa tidak ada keseragaman di antara manusia, melainkan keberagaman yang tanpa akhir. Di dalam penciptaan, Tuhan telah menetapkan perbedaan antara perempuan dan laki-laki. Karunia dan bakat fisik dan rohani menunjukkan keberagaman di antara manusia. Di dalam cara yang unik, keberagaman agama juga hadir. Kuyper menggunakan istilah multiformity untuk menunjuk pada sejumlah bidang kehidupan yang bersifat kolektif. Dengan konsep multiformity, dia menolak kesatuan gereja yang kelihatan dan menganjurkan gereja yang "multiform", yaitu keberagaman denominasi yang statusnya setara di dalam negara. Dia memperluas konsep multiformity pada bidang kebudayaan yang lebih luas, yaitu mendukung keberagaman perkumpulan yang memperhitungkan masyarakat sipil yang beragam sebagai perwujudan tujuan Allah dalam mengembangkan kehidupan budaya yang kaya dan kompleks sesuai dengan Kejadian 1:28: "bertambah banyak; dan penuhilah bumi". ${ }^{14}$ Visinya tentang pluralisme berpusat pada kedaulatan Allah atas semua aspek realitas, kehidupan, pemikiran dan kebudayaan, sehingga ketaatan dan ketidaktaatan kepada Allah berhubungan dengan pandangan dunia seseorang. Kuyper menekankan pokok-pokok penting tentang ciptaan, kejatuhan dan penebusan, yaitu:

- Gagasan bahwa anugerah Allah yang bersifat menebus telah memulihkan alam semesta; bahwa keselamatan diperoleh melalui Yesus Kristus

\footnotetext{
${ }^{14}$ Ibid., 26.
} 
adalah dalam lingkup kosmik dan menuntut pembaruan segala sesuatu sesuai tujuan Allah yang semula.

- Penekanan bahwa Allah berdaulat mengatur alam semesta dan segala aspek kehidupan di dalamnya berdasarkan hukum dan firman-Nya, yang dengan cara-Nya memberi identitas khusus pada setiap hal; memelihara keberagaman ciptaan secara menakjubkan; dan mencegah perusakan atas keberadaan yang lain.

- Penekanan yang sungguh-sungguh pada mandat budaya dengan menunjukkan bahwa Allah bertujuan memberikan perkembangan progresif pada ciptaan untuk kemuliaan Allah dan untuk keuntungan manusia.

- Penekanan bahwa semua kegiatan berteori muncul dari komitmen iman yang bersumber pada akal, akan mendorong para pemikir Kristen untuk menjalani proyek akademik atas dasar kepercayaan teistik. ${ }^{15}$

\section{Pluralisme di Indonesia}

1. Pluralisme Agama dalam Konteks Indonesia

Untuk memahami pluralisme agama dalam konteks masyarakat Indonesia, penulis mengutip tulisan Fuad Zainul dalam disertasinya. Zainul mengemukakan bahwa pengertian pluralisme dalam konteks Indonesia diambil dari pemikiran beberapa tokoh Muslim dan Kristen di Indonesia. Dia mengambil pandangan dari tiga sarjana Muslim, yaitu: Nurcholish Madjid, Abdurrahman Wahid, and Quraish Shihab, sedangkan dari kalangan Kristen adalah J.B. Banawiratma, Franz-Magnis Suseno, dan Eka Darmaputera.

Nurcholish Madjid adalah tokoh Muslim dari tradisi Nahdatul Ulama
(NU) dan pernah menjabat sebagai Ketua Himpunan Mahasiswa Indonesia (HMI, 1966-1971), dosen di IAIN, peneliti LIPI, dan pendiri Yayasan Paramadina, serta penulis banyak buku. Pemikirannya mengenai pluralisme didasarkan pada pemikirannya tentang modernisasi, liberalisasi, dan sekularisasi, yaitu suatu cara berpikir ilmiah atau rasional (modernisasi), proses menggunakan caracara berpikir baru atau metodologi baru untuk memahami berbagai hal, termasuk agama (liberalisasi), dan setiap bentuk perkembangan yang membebaskan (sekularisasi). Pandangannya mengenai ketiga hal ini membuat dia memandang agama bukan sebagai institusi, melainkan sebagai spiritualitas, yakni sesuatu yang bersifat pribadi. Berdasarkan pemahamannya ini, maka pluralisme agama bagi dia adalah pengakuan akan sifat masyarakat yang majemuk, yang diikuti oleh penerimaan yang sungguhsungguh akan kemajemukan itu sebagai nilai yang positif dan rahmat Tuhan bagi umat manusia, karena hal itu dapat meningkatkan perkembangan budaya melalui interaksi dinamis dan pertukaran berbagai kebudayaan. Pluralisme sangat penting untuk menjaga stabilitas bumi dan merupakan salah satu kemurahan Tuhan yang berlimpah bagi umat manusia. Menurut Madjid, ayat-ayat Qur'an juga menyatakan fakta bahwa manusia beragam, mereka terdiri dari berbagai kelompok yang memiliki tujuan berbeda dalam kehidupan. Karena itu, setiap komunitas harus menerima keberagaman dengan memberikan kebebasan dan kesempatan satu sama lain untuk menjalankan kehidupannya sesuai dengan keyakinannya masing-masing. Mereka harus bersaing dengan cara yang sehat dan benar. Madjid percaya bahwa keberagaman agama adalah keberagaman cara menuju kepada kebenaran.

15 Ibid., 41. 
Kebenaran yang universal adalah kepercayaan kepada satu-satunya Tuhan (tauhid) yang memiliki konsekuensi ketundukan total hanya kepada Tuhan, dan inilah inti dari semua agama. Ketundukan pada Tuhan tidak berarti ketundukan pada agama tertentu. Siapa pun yang tunduk kepada Tuhan dapat juga dianggap sebagai Muslim. Jadi Islam bukanlah nama sesuatu, melainkan sebagai spiritualitas, suatu sikap mental dan spiritual yang tunduk kepada Tuhan yang esa. ${ }^{16}$

Abdurrahman Wahid adalah keturunan dari pendiri NU, salah seorang pemimpin NU, Presiden Republik Indonesia yang ke-4, pemikir agama dan politik. Pandangannya tentang pluralisme dipengaruhi oleh pemahamannya tentang demokrasi, yaitu suatu upaya untuk menyetarakan hak dan status setiap warga negara di hadapan hukum tanpa memandang etnis, agama, jenis kelamin, dan bahasa sukunya. Demokrasi berarti melindungi dan membela hak-hak kelompok-kelompok minoritas. Di dalam demokrasi terkandung nilai-nilai dasar, yaitu kemanusiaan, kesetaraan, dan keadilan. Karena itu, menurut Wahid, agama harus memajukan martabat manusia, status umat manusia yang setara di depan hukum, dan solidaritas yang benar bagi semua manusia. Wahid berusaha untuk mengimplementasikan ajaran-ajaran Islam yang inklusif dalam kerangka pluralisme dan demokrasi. Pandangannya tentang pluralisme terlihat melalui konsepnya tentang Islam sebagai agama yang penuh kasih, toleransi, keadilan, keterbukaan, egalitarian. Islam adalah agama yang mengakui bahwa semua manusia adalah setara di hadapan Tuhan. Di dalam konteks Indonesia yang

${ }^{16}$ Zainul Fuad, Religious Pluralism In Indonesia Muslim-Christian Discourse. Disertasi (Hamburg: Universität Hamburg, 2007), 110125. terdiri dari beragam agama, Islam seharusnya muncul sebagai faktor komplementer, bukan mendominasi kehidupan masyarakat. Dia lebih menekankan pentingnya spiritualitas yang dapat mengembangkan solidaritas dalam realitas pluralisme. Selain itu, Wahid juga menekankan pentingnya Pancasila sebagai prinsip yang seharusnya dipertahankan dalam hubungan antar agama karena Pancasila dapat membuat semua warga negara menikmati status yang setara di hadapan Konstitusi tanpa memandang etnik, agama, dan budaya mereka. Pancasila berfungsi sebagai aturan yang menghubungkan semua agama dalam kehidupan masyarakat. Pancasila diterima hanya sebagai dasar kehidupan sosial dan politik di Indonesia, bukan untuk dasar kehidupan beragama. ${ }^{17}$

M. Quraish Shihab adalah pakar agama terkemuka di Indonesia, rektor Institut Islam Negeri Syarif Hidayatullah Jakarta, Menteri Agama pada jaman pemerintahan Soeharto, penulis banyak buku dan artikel mengenai masalah agama. Pandangannya tentang pluralisme agama didasarkan pada pemikiran tentang kebebasan beragama yang dikembangkan dari ayat-ayat Al-Qur'an. Shihab berpendapat bahwa Islam menjamin kebebasan beragama dalam pengertian luas, termasuk kebebasan dalam berpindah agama. Perbedaan agama adalah ketentuan Tuhan. Karena itu, kaum Muslim harus toleran terhadap berbagai pandangan agama. Untuk dapat saling memahami satu sama lain, penting sekali dibangun dialog. Perbedaan agama tidak boleh merintangi hubunganhubungan sosial. ${ }^{18}$

\footnotetext{
${ }^{17}$ Ibid., 136-147.
}

${ }^{18}$ Ibid., 150-151. 
Dari perspektif Kristen, ada dua tokoh Katolik penting di Indonesia. Keduanya adalah Profesor dan teolog Katolik yang banyak menulis buku dan artikel mengenai pluralisme dan dialog antaragama, J.B. Banawiratma dan Franz-Magnis Suseno, memiliki pendapat yang sama mengenai pluralisme sebagai pengaruh dari Konsili Vatikan II (1962-1965) yang menandai keterbukaan gereja pada agama-agama lain dan penekanan pada pentingnya dialog dengan penganut agama-agama lain. Gereja Katolik mulai mengakui adanya keselamatan di dalam agama-agama lain. Atas dasar itu, Banawiratma berpendapat bahwa sikap yang tepat terhadap pluralisme agama adalah mengakui dan menerima keunikan dan makna dari setiap agama dengan menyatakan bahwa setiap orang dapat belajar dari yang lain melalui dialog antaragama. Dialog tersebut tidak hanya berbicara tentang masalah-masalah antaragama, tetapi juga meliputi interaksi komunitas-komunitas beragama dalam realitas kehidupan yang bisa mendiskusikan atau mendialogkan hal-hal apa saja menyangkut pengalaman kehidupan bersama. Magnis Suseno menekankan pentingnya etika dalam kehidupan sehari-hari dan dalam kehidupan politik bersama. Menurut dia, ada tiga hukum, yaitu hukum kekal (hikmat Allah/rencana Allah), hukum natural, dan hukum manusia. Semua tindakan dan gerakan di alam semesta dibangun dan diarahkan kepada hukum kekal. Hukum natural (akal) digunakan manusia untuk memahami rencana Allah dan mendapatkan tujuan yang tepat berdasarkan akal mereka melalui tindakan Allah dalam ciptaan. Dengan hukum natural, terbuka kemungkinan untuk memahami orang-orang yang tidak percaya pada Allah atau seorang ateis yang dapat juga memiliki kehidupan yang

${ }^{19}$ Ibid., 160-161. baik di hadapan Allah. Hukum natural adalah area di mana orang Kristen dan para penganut lain menemukan dasar untuk bekerjasama dalam tindakan etis dan moral. Dua nilai sosial yang fundamental, yaitu kebenaran dan perdamaian yang riil adalah jaminan keberlangsungan masyarakat dan para anggotanya. ${ }^{19}$

Dari perspektif Protestan, pandangan Eka Darmaputera tentang pluralisme dipengaruhi oleh konsultasi WCC di Kandi tahun 1967, yang berfokus pada dialog orang Kristen dengan para penganut agama-agama lain. Sama seperti kalangan Katolik, di kalangan Protestan juga sudah ada pengakuan akan kemungkinan adanya keselamatan di dalam agama-agama lain melalui aktivitas universal dari Roh Kudus. ${ }^{20}$

\section{Permasalahan Pluralisme Agama di Indonesia}

Permasalahan pluralisme agama di Indonesia sangat rumit. Konflik agama sangat mudah terjadi di Indonesia. Sudah banyak upaya dilakukan untuk mengatasinya, namun menjaga dan mempertahankan kerukunan antar agama tetap merupakan kerja keras masyarakat, para pemimpin agama, dan pemerintah. Ada dua tulisan di bawah ini yang menunjukkan masalah pluralisme tetap menjadi perhatian bersama. Priyono dalam tulisannya mengemukakan bahwa fakta kemajemukan masyarakat Indonesia adalah realitas yang tidak dapat dielakkan. Akan tetapi kemajemukan tersebut juga memiliki potensi terjadinya konflik kepentingan antar kelompok penganut agama yang disebabkan oleh berbagai hal, yaitu: setiap agama memiliki tugas dakwah/misi dari agamanya masing-masing; kurangnya

${ }^{20}$ Ibid., 162-163. 
pemahaman para pemeluk agama akan agamanya sendiri dan pihak lain; tidak jelasnya batas antara sikap memegang teguh keyakinan agama dan toleransi beragama; prasangka masing-masing pihak akan kejujuran pihak lain baik dalam internal umat beragama, antarumat beragama, maupun antara umat beragama dengan pemerintah; kesenjangan yang tajam dalam hal sosial, ekonomi dan pendidikan antara berbagai golongan agama; kurangnya komunikasi antar pemimpin umat beragama; dan kecenderungan fanatisme yang berlebihan. $^{21}$

Ahmad Khaerurrozikin dalam artikelnya Problem Sosiologis Pluralisme Agama di Indonesia menyatakan bahwa kemunculan paham pluralisme agama di Indonesia juga telah menimbulkan masalah bagi agamaagama, yaitu karena pluralisme agama telah menganggap semua agama adalah sama dan keselamatan juga ada pada agama-agama lain. Menanggapi hal tersebut, ada tokoh-tokoh Kristen yang menolak pluralisme agama, demikian juga fatwa MUI tahun 2005 telah mengharamkan pluralisme agama karena pluralisme agama bertentangan dengan ajaran Islam. Khaerurrozikin sendiri menolak pluralisme agama sebagai solusi yang tepat untuk mengatasi permasalahan agama di Indonesia karena paham tersebut hendak merelatifkan kebenaran dari semua agama. Dia lebih menekankan pentingnya menjalankan prinsip kemanusiaan yang diajarkan dalam agama Islam, yaitu sikap toleransi yang dibangun atas dasar kebaikan atau kasih kepada penganut agama lain, yang memang diperintahkan oleh Tuhan, tanpa

\footnotetext{
${ }^{21}$ Priyono, Pluralisme Agama dan Konflik. Jurnal Analisa volume XV, no. 02, Mei -Agustus 2008:130.

https://media.neliti.com/media/publications/16 2926-ID-pluralisme-agama-dan-konflik.pdf.
}

harus mengorbankan akidah agama dan keyakinan bahwa ajaran agamanya adalah yang paling benar di hadapan Allah. ${ }^{22}$ Permasalahan menyangkut pluralisme agama dalam konteks Indonesia sangat penting dipahami sehingga dapat dilihat kontribusi pemikiran Kuyper untuk pengembangan pendidikan agama Kristen.

\section{Pengembangan Konsep Pluralisme Agama dalam Pendidikan Agama Kristen}

Beberapa pokok pikiran Kuyper yang dapat dikembangkan dalam pengajaran pendidikan agama Kristen di Indonesia, yaitu:

1. Sejak semula Tuhan menjadikan dunia dan segala isinya dalam keberagaman (multiformity) dengan tujuan untuk mengembangkan kehidupan budaya (Kej. 1:28). Keberagaman itu terlihat dalam segala bidang kehidupan. Karena itu, keberagaman harus dipandang sebagai suatu kemutlakan dan karunia yang berasal dari Tuhan. Secara khusus, keberagaman agama adalah pengembangan mandat budaya, yang dipahami juga sebagai anugerah umum Allah. PAK harus mampu menyampaikan pemahaman ini kepada peserta didik sehingga mereka bisa menerimanya sebagai bagian dari keyakinan Kristiani. Tuhan adalah pencipta yang berdaulat atas keberagaman agama. Mengganggu dan merusak keberagaman sama artinya dengan menentang Tuhan yang berdaulat.

2. Agama dibentuk untuk kemuliaan Tuhan yang berfungsi untuk

22 Ahmad Khaerurrozikin, Problem Sosiologis Pluralisme Agama di Indonesia. Jurnal Kalimah, volume 13 No. 1, Maret 2015: 85, 101. 
menghasilkan kebaikan dan berkat bagi manusia. Pendidikan agama Kristen sebagai upaya mendidik semua orang Kristen dari segala usia di lingkup keluarga, gereja, sekolah, dan masyarakat, dilakukan secara sistematis dan berkesinambungan dengan tujuan untuk mendewasakan iman dan membangun karakter mereka menurut nilai-nilai Kristen. Salah satu pokok yang harus ditanamkan melalui pendidikan ini adalah pemahaman dan sikap yang benar mengenai keberagaman agama. Orang Kristen harus memiliki kedewasaan iman dan karakter agar mampu menerima, menghargai, dan mendukung keberagaman masyarakat, dan melihat keberagaman itu sebagai suatu anugerah Tuhan yang patut dipelihara dan dipertahankan untuk mewujudkan kebaikan bagi semua orang. Para pengajar agama Kristen harus mendesain kurikulum dan metode pembelajaran PAK yang mendukung pemahaman pluralisme agama dan pengalaman riil dalam mewujudkan kebaikan bagi masyarakat pluralis. Untuk hasil yang efektif, para pengajar PAK dituntut harus mampu bukan hanya sebagai perancang kurikulum dan pembelajaran, tetapi juga harus mampu menjadi pemimpin dalam pendidikan agama. Marien de Souza menyatakan pemimpin dalam pendidikan agama haruslah memiliki kecerdasan rohani yang dicirikan oleh empat ciri, yaitu: 1) memiliki kesadaran diri dan fleksibilitas yang tinggi; 2) memiliki kapasitas untuk menghadapi dan mengelola

${ }^{23}$ Marian de Souza. 2009. Spiritual Intelligence and its Contribution to Religious Education Leadership in a Time of Religious Pluralism and Divisiveness. Dalam Wilna A.J. Meijer, penderitaan, serta mengalahkan kepedihan; 3) memiliki kualitas yang diinspirasi oleh visi dan nilai-nilai; suatu kecenderungan untuk melihat hubungan di antara berbagai hal (holistik); dan kesukaan menciptakan perdamaian bagi orang lain; 4) kecenderungan untuk mengajukan pertanyaan "mengapa" dan "bagaimana" terhadap konsep di balik berbagai tantangan kebudayaan yang menguasai masyarakat." 23 Dengan kecerdasan rohani ini, para pengajar PAK dapat menanamkan nilai-nilai pengajaran yang baik karena disertai keteladanan.

3. Pengakuan akan keberagaman agama merupakan pengakuan atas manusia sebagai gambar Allah. Atas dasar ini, dalam PAK harus ditekankan bahwa setiap manusia setara dan berharga di hadapan Allah, apapun agamanya. Setiap manusia berhak mengupayakan persekutuannya secara langsung dengan Allah tanpa harus diintervensi atau ditekan oleh manusia lainnya. Tidak boleh ada manusia yang bertindak sebagai hakim yang mengadili keyakinan seseorang sejauh hal itu tidak merugikan atau membahayakan kehidupan orang lain. Setiap orang berdiri di hadapan Allah sebagai Hakimnya. PAK harus mengupayakan metode-metode belajar yang inovatif dan kreatif untuk mendidik para murid dalam mengimplementasikan konsep manusia sebagai gambar Allah. Melalui penggunaan metode-metode belajar tersebut, para murid dilatih untuk berpikir rasional mengenai agama mereka dan bisa merasakan

Siebren Miedema, Alma Lanser-van der Velde (eds.), Religious Education in a World of Religious Diversity. Munster, New York, Munchen, Berlin: Waxmann, 175-176. 
bahwa agama mereka diterima dan dihargai. Hal ini akan menumbuhkan spiritualitas yang sehat dalam kehidupan para murid yang berakibat pada perilaku dan kontribusi positif dalam masyarakat luas.

4. Pendidikan Agama Kristen harus memiliki kepedulian untuk membicarakan masalah-masalah menyangkut keberagaman agama, misalnya: posisi suatu agama di antara agama-agama lain (sebagai komplementer); fungsi agama (untuk kebaikan dan memajukan martabat semua orang); pemahaman teologis keberagaman agama (sebagai ketentuan Allah); pentingnya metode dialog antaragama dalam proses pembelajaran PAK; pentingnya etika umum dan politik untuk menjaga keberagaman agama melalui penggunaan hukum natural (akal) dalam memahami tujuan dan rencana Allah dalam kehidupan manusia dan ciptaan lainnya; penyebab dan potensi konflik antaragama, yaitu: misi/dakwah setiap agama; kurangnya pemahaman akan agamanya dan agama lain; batas keyakinan agama dan toleransi beragama; prasangka internal agama dan antar umat beragama, umat beragama dan pemerintah; kesenjangan sosial, ekonomi, pendidikan; kurangnya komunikasi antar pemimpin agama; dan fanatisme agama yang berlebihan. Semua hal ini perlu disampaikan melalui PAK kepada semua umat Kristen untuk meruntuhkan prasangka-prasangka,

kesalahpahaman, ketidakpercayaan, dan tindakan pengucilan yang mungkin terjadi dalam hubungan antaragama. Hal ini bisa terjadi di mana saja sehingga para pengajar PAK harus mampu mengantisipasi hal-hal yang mungkin terjadi. Dalam hal ini, konsep pluralisme agama menurut Kuyper dapat dikembangkan untuk membantu mengatasi masalahmasalah keberagaman agama di Indonesia.

\section{E. Kesimpulan}

Pluralisme agama atau keberagaman agama dalam pemikiran Kuyper terbentuk dari pemikiran dan sikap yang dibangun dari pokok kebebasan dan teologi Calvinis yang berkembang di Amerika. Kebebasan tersebut mencakup kebebasan hati nurani, kebebasan gerejawi, kebebasan asosiasi, dan kebebasan politik. Sementara itu, teologi Calvinis yang dipahami dalam pengertian scientific, historis, filosofis, dan politis telah menghasilkan pemikiran tentang bentuk gereja yang beragam; bentuk kehidupan manusia yang sangat beragam, cara keberadaan yang beragam, serta cita-cita dan konsepsi yang beragam, khususnya yang terwujud dalam konsep keberagaman agama.

Keberagaman agama bagi Kuyper adalah tujuan dan rencana Allah dari sejak awal penciptaan. Keberagaman agama adalah karunia Tuhan; refleksi kebebasan hati nurani. Keberagaman agama diijinkan Tuhan terjadi untuk menghasilkan perkembangan kebudayaan dan kebaikan manusia; dan sebagai pengakuan akan keberadaan manusia sebagai gambar Allah. Pendidikan Agama Kristen sebagai upaya pendewasaan seluruh warga jemaat harus mengembangkan pendidikan yang memajukan keberagaman agama sehingga seluruh pembelajar mampu mengelola keberagaman tersebut untuk tujuan dan manfaat yang positif, serta mampu mengatasi konflik atau benturan terkait keberagaman agama di Indonesia. 


\section{F. Referensi}

de Souza, Marian. Spiritual Intelligence and its Contribution to Religious Education Leadership in a Time of Religious Pluralism and Divisiveness. Dalam Wilna A.J. Meijer, Siebren Miedema, Alma Lanser-van der Velde (eds.), Religious Education in a World of Religious Diversity. Munster, New York, Munchen, Berlin: Waxmann, 2009.

Fuad, Zainul, Religious Pluralism In Indonesia Muslim-Christian Discourse. Disertasi. Hamburg: Universität Hamburg, 2007.

Khaerurrozikin, Ahmad, Problem Sosiologis Pluralisme Agama di Indonesia. Jurnal Kalimah volume 13 No. 1, Maret 2015: 85-101.

Kromminga, John H., Abraham Kuyper. Dalam Elmer L. Towns (ed.), A History of Religious Educators. www.elmertowns.com.

Kuyper, Abraham. Lectures on Calvinism: Six Lectures Delivered at Princeton University Under Auspices of the L. P. Stone Foundation. Grand Rapids , Michigan: Wm. B. Eerdmans Publishing Company, 1999.

Kuyper, Abraham. Lectures on Calvinism: Six Lectures from the Stone Foundation Lectures Delivered at Princeton University. USA: ReadaClassic.com., 2010.

Mouw, Richard J. The Challenges of Cultural Discipleship: Essays in the Line of Abraham Kuyper. Grand Rapids, Michigan: William B. Eerdmans, 2012.

Naugle, David K., Worldview: The History of A Concept. Grand Rapids, Michigan: William B. Eerdmans Publishing Company, 2002.

Priyono, Pluralisme Agama dan Konflik. Jurnal Analisa Volume XV, No. 02, Mei-Agustus 2008: 129-137.

Witte, Jr. John, The Biography and Biology of Liberty: Abraham Kuyper and the American Experiment. Dalam Luis E.
Lugo, ed., Religion, Pluralism, and Public Life: Abraham Kuyper's Legacy for the 21st Century. Grand Rapids, MI: Wm. B. Eerdmans Publishing Co., 2000. 